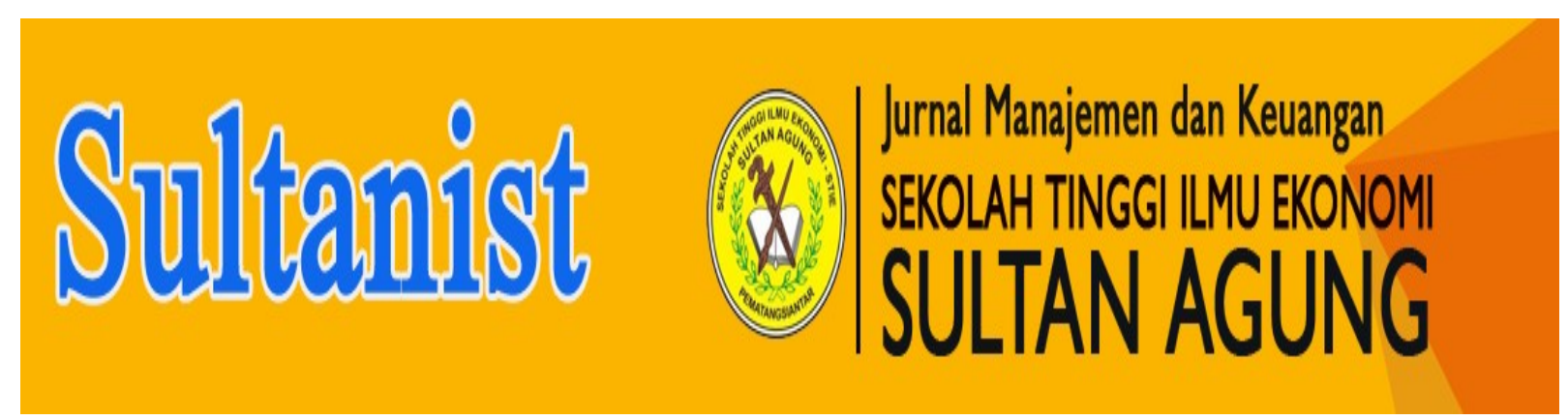

\title{
PENGARUH LIKUIDITAS, UKURAN PERUSAHAAN DAN PROFITABILITAS TERHADAP NILAI PERUSAHAAN PADA PERUSAHAAN SUB SEKTOR KERAMIK PORSELIN DAN KACA YANG TERDAFTAR DI BURSA EFEK INDONESIA
}

\author{
Oleh: \\ Jenny Frida Br Nainggolan \\ S1 Akuntansi \\ Yansen Siahaan, Jubi, Ady Inrawan
}

Tujuan dari penelitian ini adalah 1. Untuk mengetahui likuiditas, ukuran perusahaan, profitabilitas dan nilai perusahaan pada Perusahaan Sub Sektor Keramik, Porselin dan Kaca yang terdaftar di Bursa Efek Indonesia. 2. Untuk mengetahui pengaruh likuiditas, ukuran perusahaan, profitabilitas dan nilai perusahaan pada Perusahaan Sub Sektor Keramik, Porselin, dan Kaca yang terdaftar di Bursa Efek Indonesia baik secara simultan maupun parsial. Penelitian ini dilakukan dengan menggunakan analisis deskriptif kuantitatif dan analisis deskriptif kuantitatif. Objek penelitian adalah Perusahaan Sub Sektor Keramik, Porselin dan Kaca yang terdaftar di Bursa Efek Indonesia. Pengumpulan data dilakukan dengan metode dokumentasi. Teknik analisis yang digunakan adalah uji asumsi klasik, analisis regresi linear berganda koefisien korelasi, koefisien determinasi, uji hipotesis. Analisis ini dilakukan dengan menggunakan Program IBM SPSS Statistic versi 21,0.

Hasil penelitian ini dapat disimpulkan sebagai berikut: 1. secara keseluruhan nilai rata-rata Current Ratio (CR) mengalami fluktuasi cenderung meningkat 2. secara keseluruhan nilai rata-rata size mengalami fluktuasi cenderung meningkat. 3. secara keseluruhan nilai rata-rata Return on Assets (ROA) mengalami fluktuasi namun cenderung menurun. 4. uji $\mathrm{F}$ diperoleh bahwa secara simultan besarnya $F_{\text {hitung }}>F_{\text {tabel }} H_{0}$ ditolak, artinya bahwa likuiditas, ukuran perusahaan, dan profitabilitas berpengaruh tidak signifikan terhadap nilai perusahaan pada Perusahaan Sub Sektor Keramik, Porselin, dan Kaca yang terdaftar di Bursa Efek Indonesia tahun 2013-2017.

Kata Kunci: Likuiditas, Ukuran Perusahaan, Profitabilitas dan Nilai Perusahaan

\section{ABSTRACT}

The purpose of this study is 1. To determine the liquidity, company size, profitability and value of the company in the Ceramic, Porcelain and Glass Sub-Sector Companies listed on the Indonesia Stock Exchange. 2. To determine the effect of liquidity, company size, profitability and firm value on the Ceramic, Porcelain and Glass Sub-Sector Companies listed on the Indonesia Stock Exchange both simultaneously and partially. This research was conducted using quantitative descriptive analysis and quantitative descriptive analysis. The object of the research is the Ceramic, Porcelain and Glass SubSector Company listed on the Indonesia Stock Exchange. Data collection is done by documentation method. The analysis technique used is the classical assumption test, multiple linear regression analysis correlation coefficient, determination coefficient, hypothesis testing. This analysis was carried out using the IBM SPSS Statistic Program version 21.0.

The results of this research can be concluded as follows: 1. Overall average value of Current Ratio (CR) fluctuates tends to increase 2. overall the average value of size has fluctuated tends to increase. 3. overall the average value of Return on Assets (ROA) fluctuates but tends to decrease. 4. $F$ test found that simultaneously the magnitude of Fcount> Ftable of $\mathrm{HO}$ is rejected, meaning that liquidity, firm size, and profitability have no significant effect on the value of the company in the Ceramic, Porcelain and Glass Sub-Sector Company listed on the Indonesia Stock Exchange in 20132017.

Keywords: Liquidity, Company Size, Profitability and Company Value

\section{A. PENDAHULUAN}

\section{Latar Belakang Masalah}

Di era globalisasi saat ini perkembangan ekonomi telah membuat persaingan antar perusahaan semakin ketat. Persaingan yang ketat dalam berbagai aspek merupakan hal yang tidak dapat dihindari terutama dalam dunia bisnis. Tujuan utama dari perusahaan

SULTANIST: Jurnal Manajemen dan Keuangan adalah meningkatkan kemakmuran pemilik perusahaan atau para pemegang saham melalui peningkatan nilai perusahaan. Nilai perusahaan ini digunakan untuk mengukur keberhasilan perusahaan karena dengan meningkatkan nilai perusahaan, maka kemakmuran pemilik perusahaan dan pemegang saham juga akan meningkat. 
Terdapat beberapa rasio dan informasi keuangan perusahaa yang dapat digunakan untuk memprediksi nilai perusahaan. Rasio keuangan yang dapat memprediksi nilai perusahaan yaitu likuiditas, ukuran perusahaan dan profitabilitas.

Gambaran Current Ratio (CR), Size, Return on Assets (ROA) dan Price to book Value pada Perusahaan Sub Sektor Keramik, Porselin, dan Kaca Periode 2013-2017 sebagai berikut:

Tabel 1

Gambaran Current Ratio (CR), Size, Return on Assets (ROA) dan Price to book Value pada Perusahaan Sub Sektor Keramik, Porselin, dan Kaca Periode 20132017

\begin{tabular}{|c|c|c|c|c|}
\hline Tahun & $\begin{array}{c}\text { CR } \\
\text { (kali) }\end{array}$ & $\begin{array}{c}\text { Size } \\
\text { (Kali) }\end{array}$ & $\begin{array}{c}\text { ROA } \\
\text { (Kali) }\end{array}$ & $\begin{array}{c}\text { PBV } \\
\text { (Kali) }\end{array}$ \\
\hline 2013 & 3,71 & 29,16 & 0,07 & 0,92 \\
\hline 2014 & 1,23 & 27,98 & 0,12 & 5,16 \\
\hline 2015 & 4,09 & 28,35 & $-0,04$ & 0,8 \\
\hline 2016 & 0,97 & 29,55 & $-0,01$ & 0,7 \\
\hline 2017 & 2,24 & 28,46 & 0,11 & 1,37 \\
\hline Rata-rata & 2,45 & 28,7 & 0,05 & 1,79 \\
\hline
\end{tabular}

\section{Rumusan Masalah}

a. Bagaimana likuiditas, ukuran perusahaan, profitabilitas dan nilai perusahaan pada Perusahaan Sub Sektor Keramik, Porselin, dan Kaca yang terdaftar di Bursa Efek Indonesia.

b. Bagaimana pengaruh likuiditas, ukuran perusahaan, profitabilitas dan nilai perusahaan pada Perusahaan Sub Sektor Keramik, Porselin, dan Kaca yang terdaftar di Bursa Efek Indonesia baik secara simultan maupun parsial.

\section{Tujuan Penelitian}

a. Untuk mengetahui gambaran likuiditas, ukuran perusahaan, profitabilitas dan nilai perusahaan pada Perusahaan Sub Sektor Keramik, Porselin, dan Kaca yang terdaftar di Bursa Efek Indonesia.

b. Untuk mengetahui pengaruh likuiditas, ukuran perusahaan, profitabilitas dan nilai perusahaan pada Perusahaan Sub Sektor Keramik, Porselin, dan Kaca yang terdaftar di Bursa Efek Indonesia baik secara simultan maupun parsial.

\section{Metodologi Penelitian}

Penelitian ini menggunakan data sekunder dengan cara mengakses dari situs http://www.idx.co.id. Desain penelitian ini terdiri dari penelitian kepustakaan (library research). Teknik mengumpulkan data dengan metode dokumentasi. Teknik analisis data yaitu dengan uji asumsi klasik kemudian dianalisis secara deskriptif kualitatif dan kuantitatif.

\section{B. LANDASAN TEORI}

\section{Laporan Keuangan}

Menurut Kieso, Jerry, dan Terry (2007:2), "laporan keuangan merupakan sarana pengkomunikasian informasi keuangan utama pihak-pihak di luar perusahaan".

Menurut Kasmir (2012:6), "laporan keuangan adalah laporan yang menunjukkan kondisi keuangan perusahaan pada saat ini atau dalam suatu periode tertentu".

\section{Tujuan Laporan Keuangan}

Menurut Kartikahadi (2012:118), tujuan laporan keuangan adalah memberikan informasi mengenai keuangan, kinerja keuangan, dana arus kas yang bermanfaat bagi sebagian besar pengguna laporan keuangan dalam membuat keputusan ekonomi Kasmir (2010:87), ada beberapa tujuan dalam penyusunan laporan keuangan yaitu:

1. Memberikan informasi tentang jenis dan jumlah aset (harta) yang dimiliki perusahaan pada saat ini.

2. Memberikan informasi tentang jenis dan jumlah kewajiban dan jumlah modal yang dimiliki perusahaan pada saat nanti.

3. Memperlihatkan informasi mengenai jenis serta jumlah pendapatan yang diperoleh dalam suatu periode tertentu.

4. Memberikan informasi mengenai jumlah biaya (beban) serta jenis biaya yang di keluarkan perusahaan dalam suatu periode tertentu.

5. Memberikan informasi tentang perubahan yang terjadi terhadap aset, kewajiban, dan modal perusahaan.

6. Memberikan informasi tentang catatan atas laporan keuangan.

7. Infomasi keuangan lainnya.

\section{Rasio Keuangan}

Menurut Kasmir (2010:93), "rasio keuangan merupakan kegiatan membandingkan angkaangka yang ada dalam laporan keuangan dengan cara membagi satu angka dengan angka lainnya".

Menurut Brigham dan Joel (2012:133), "rasio keuangan (di analisis) berguna untuk membantu mengantisipasi kondisi masa depan, yang lebih penting lagi adalah titik awal untuk merencanakan tindakan-tindakan yang akan memperbaiki kinerja dimasa depan ".

\section{Likuiditas}

Menurut Brigham dan Joel (2012:134), "rasio likuiditas merupakan rasio yang menunjukkan antara kas dan aset lancar perusahaan lainnya dengan kewajiban lancarnya".

Likuiditas kemampuan perusahaan untuk memenuhi kewajiban jangka pendeknya. 
$\begin{array}{cc}\text { Menurut } & \text { Kasmir } \\ \text { meno:110), }\end{array}$ merupakan rasio yang menggambarkan kemampuan perusahaan memenuhi kewajiban (hutang jangka pendek).

\section{Ukuran perusahaan}

Menurut Riyanto (2009:1), "suatu perusahaan besar dengan saham terbesar sangat luas, perluasan saham akan mempunyai pengaruh yang kecil terhadap kemungkinan hilang atau tergesernya kontrol dari pihak dominan dari perusahaan yang bersangkutan. Sebaliknya, perusahaan kecil yang sahamnya sangat tersebar dilingkungan kecil, penambahan jumlah saham akan mempunyai pengaruh yang paling besar terhadap kemungkinan hilangnya kontrol pihak dominan terhadap perusahaan yang bersangkutan".

Sedangkan menurut Brigham dan Joel (2001:117), "ukuran perusahaan adalah ratarata penjualan bersih untuk tahun yang bersangkutan sampai beberapa tahun".rasio yang digunakan biasanya adalah Size $=\mathrm{Ln}$ Total Aset.

\section{Profitabilitas}

Menururt Brigham dan Joel (2012:146) menyatakan "rasio profitabilitas mencerminkan hasil akhir dari seluruh kebijakan keuangan dan keputusan operasional".

Sementara menurut Hery (2010:554), "rasio profitabilitas merupakan rasio yang digunakan untuk mengukur kemampuan perusahaan dalam menghasilkan laba dari aktivitas normal bisnisnya.

\section{Nilai Perusahaan}

Menurut Keown, et.al. (2004:470), "nilai perusahaan merupakan pasar berdasarkan surat berharga dan ekuitas perusahaan yang beredar. Bagi para pemgang saham atau Price to Book Value, harga pasar saham perusahaan menggambarkan nilai perusahaan termasuk seluruh kompleksitas dan risiko dunia nyata".

Menurut Brigham dan Joel (2010:91), "nilai perusahaan adalah rasio yang menghubungkan harga saham perusahaan dengan laba dan nilai buku per saham." Rasio ini memberi indikasi kepada manajemen mengenai pendapat investor tentang prestasi perusahaan di masa lalu dan prospeknya di masa mendatang. Perusahaan yang dianggap baik oleh investor adalah perusahaan dengan laba dan arus kas yang aman, mengalami pertumbuhan, dijual dengan rasio nilai buku yang lebih tinggi dibandingkan perusahaan dengan tingkat pengembalian yang rendah.

\section{Pengaruh Likuiditas, Ukuran Perusahaan dan Profitabilitas terhadap Nilai Perusahaan}

$\begin{array}{cr}\text { Menurut Kasmir } & (2010: 110) \text {, } \\ \text { menyebutkan bahwa rasio } & \text { likuiditas }\end{array}$ merupakan rasio yang menggambarkan kemampuan perusahaan memenuhi kewajiban (hutang jangka pendek). Selanjutnya menurut Kasmir (2010:110), "bila nilai likuiditas terlampau tinggi akan berpengaruh kurang baik terhadap laba perusahaan, karena ada sebagian dana yang tidak produktif yang diinvestasikan dalam current ratio asset, akhirnya profitabilitas perusahaan tidak optimal" berdasarkan teori dapat diketahui apabila laba perusahaan turun maka nilai perusahaan juga turun. Sasaran likuiditas suatu perusahaan adalah likuiditas yang mampu untuk membayar utang-utang perusahaan terutama utang jangka pendek apabila perusahaan ditagih.

Selain likuiditas, nilai perusahaan juga dapat dipengaruhi oleh ukuran perusahaan

Menurut Brigham dan Joel (2010:150), mengatakan "jika rasio likuiditas, manajemen aset, manjemen hutang, dan profitabilitas semuanya terlihat baik jika kondisi ini berjalan secara terus menerus secara stabil maka rasio pasar akan tinggi, harga saham kemungkinan akan tinggi sesuai dengan yang diperkirakan ukuran perusahaan yang tinggi menunjukkan bahwa nilai perusahaan akan tinggi. Kemudian nilai perusahaan juga dipengaruhi oleh profitabilitas. Menurut Brigham dan Joel (2012:150), profitabilitas adalah kemampuan perusahaan memperoleh laba dalam periode tertentu pada tingkat penjualan, aset dan modal saham tertentu. Salah satu parameter yang digunakan untuk mengukur besar kecilnya profitabilitas adalah dengan menggunakan Return on Assets (ROA). ROA untuk mengukur kemampuan perusahaan dalam menghasilkan laba bersih dengan total aset. Dengan semakin tingginya nilai ROA maka semakin baik kondisi perusahaan dan semakin besar juga laba yang diperoleh perusahaan.

\section{PEMBAHASAN}

1. Analisis

a. Analisis Deskriptif Kualitatif

1) Gambaran Likuiditas pada Perusahaan Sub Sektor Keramik, Porselen dan Kaca yang terdaftar di Bursa Efek Indonesia periode tahun 2013-2017

Berikut ini gambaran likuiditas perusahaan Sub Sektor Keramik, Porselen dan Kaca yang diukur dengan Current Ratio (CR):

Tabel 2

Gambaran CR Perusahaan Sub Sektor Keramik, Porselen dan Kaca di Bursa Efek Indonesia periode tahun 2013-2017 


\begin{tabular}{|c|c|c|c|c|c|c|c|}
\hline & Emiten & (Kali) & (Kali) & (Kali) & (Kali) & (Kali) & rata \\
\hline 1 & AMFG & 4,18 & $\mathbf{5 , 6 8}$ & 4,65 & 2,02 & 2,01 & $\mathbf{3 , 7 1}$ \\
\hline 2 & ARNA & 1,30 & 1,61 & 1,02 & 1,35 & 0,89 & $\mathbf{1 , 2 3}$ \\
\hline 3 & KIAS & 5,27 & 5,61 & 3,33 & 3,13 & 3,11 & $\mathbf{4 , 0 9}$ \\
\hline 4 & MLIA & 1,13 & 1,11 & 0,87 & $\mathbf{0 , 8 6}$ & 0,87 & $\mathbf{0 , 9 7}$ \\
\hline 5 & TOTO & 2,19 & 2,11 & 2,41 & 2,19 & 2,30 & $\mathbf{2 , 2 4}$ \\
\hline $\begin{array}{c}\text { Rata-rata per } \\
\text { Tahun }\end{array}$ & 2,81 & 3,22 & 2,46 & 1,91 & 1,84 & $\mathbf{2 , 4 5}$ \\
\hline \multicolumn{7}{|c|}{ CR (Current Ratio) Minimum } \\
\hline \multicolumn{7}{|c|}{ Rata-rata CR (Current Ratio) } & $\mathbf{0 , 8 6}$ \\
\hline \multicolumn{7}{|c|}{ ( Cutrent Ratio) Maksimum } & $\mathbf{5 , 6 8}$ \\
\hline
\end{tabular}

Sumber : Data Diolah

Dari tabel 2, terlihat bahwa keadaan rata-rata likuiditas Perusahaan Sub Sektor Keramik, Porselen dan Kaca periode 20132017 berfluktuasi dan cenderung menurun. Hal ini disebabkan aset lancar yang dimiliki perusahaan jauh lebih besar dari aset lancar yang dimiliki perusahaan.

2) Gambaran Ukuran Perusahaan pada Perusahaan periode 2013-2017

Berikut ini Ukuran Perusahaan pada Perusahaan Sub Sektor Keramik, Porselen dan Kaca yang diproksikan dengan Size dalam Tabel 3:

\section{Tabel 3}

Gambaran Size pada Perusahaan Sub Sektor Keramik, Porselen dan Kaca Periode 2013-2017 Sumber : Data Diolah

Dari tabel 3, rata-rata ukuran perusahaan Perusahaan Sub Sektor Keramik, Porselen dan Kaca periode 2013-2017 berfluktuasi dan cenderung mengalami peningkatan. Hal ini disebabkan oleh meningkatnya perolehan jumlah aset perusahaan.

\section{3) Gambaran Profitabilitas pada \\ Perusahaan Periode 2013-2017}

Berikut ini Profitabilitas pada pada Perusahaan Sub Sektor Keramik, Porselin dan Kaca yang terdaftar di Bursa Efek Indonesia periode tahun 2013-2017 berfluktuasi dan

\begin{tabular}{|c|c|c|c|c|c|c|c|}
\hline NO & $\begin{array}{c}\text { Kode } \\
\text { Emiten }\end{array}$ & $\begin{array}{l}2013 \\
\text { (Kali) }\end{array}$ & $\begin{array}{l}2014 \\
\text { (Kali) }\end{array}$ & $\begin{array}{l}2015 \\
\text { (Kali) }\end{array}$ & $\begin{array}{l}2016 \\
\text { (Kali) }\end{array}$ & $\begin{array}{l}2017 \\
\text { (Kali) }\end{array}$ & $\begin{array}{l}\text { Rata- } \\
\text { rata }\end{array}$ \\
\hline 1 & AMFG & 28,89 & 29,00 & 29,08 & 29,34 & 29,47 & 29,16 \\
\hline 2 & ARNA & 27,76 & 27,86 & 27,99 & 28,06 & 28,10 & 27,95 \\
\hline 3 & KIAS & 28,45 & 28,49 & 28,38 & 28,25 & 28,20 & 28,35 \\
\hline 4 & MLIA & 29,60 & 29,61 & 29,59 & 29,68 & 29,28 & 29,55 \\
\hline 5 & TOTO & 28,19 & 28,34 & 28,52 & 28,58 & 28,67 & 28,46 \\
\hline \multicolumn{2}{|c|}{$\begin{array}{c}\text { Rata-rata per } \\
\text { Tahun }\end{array}$} & 28,58 & 28,66 & 28,71 & 28,78 & 28.74 & 28.70 \\
\hline \multicolumn{7}{|c|}{ Size Minimum } & 27,76 \\
\hline \multirow{2}{*}{\multicolumn{7}{|c|}{ Size Maksimum }} & 29,68 \\
\hline & & & & & & & 28,70 \\
\hline
\end{tabular}

cenderung menurun. Hal ini disebabkan laba bersih yang dimiliki perusahaan jauh lebih rendah dari total aset yang dimiliki perusahaan.

\section{4) Gambaran Nilai Perusahaan Perusahaan} pada Perusahaan Periode 2013-2017

Berikut ini nilai perusahaan Perusahaan Sub Sektor Keramik, Porselen dan Kaca yang diproksikan dengan menggunakan rasio Price to Book Value (PBV) yang disajikan dalam Tabel 4 berikut ini:

\section{Tabel 4}

Gambaran PBV Perusahaan Sub Sektor Keramik, Porselen dan Kaca di Bursa Efek Indonesia periode tahun 2013-2017

\begin{tabular}{|c|c|c|c|c|c|c|c|}
\hline NO & $\begin{array}{c}\text { Kode } \\
\text { Emiten }\end{array}$ & $\begin{array}{l}2013 \\
\text { (Kali) }\end{array}$ & $\begin{array}{l}2014 \\
\text { (Kali) }\end{array}$ & $\begin{array}{l}2015 \\
\text { (Kali) }\end{array}$ & $\begin{array}{l}2016 \\
\text { (Kali) }\end{array}$ & $\begin{array}{l}2017 \\
\text { (Kali) }\end{array}$ & $\begin{array}{l}\text { Rata- } \\
\text { rata }\end{array}$ \\
\hline 1 & AMFG & 0,10 & 0,12 & 0,08 & 0,05 & 0,01 & 0,07 \\
\hline 2 & ARNA & 0,21 & 0,21 & 0,05 & 0,06 & 0,08 & 0,12 \\
\hline 3 & KIAS & 0,03 & 0,04 & $-0,08$ & $-0,14$ & $-0,05$ & $-0,04$ \\
\hline 4 & MLIA & $-0,07$ & 0,02 & $-0,02$ & 0,00 & 0,01 & $-0,01$ \\
\hline 5 & TOTO & 0,14 & 0,14 & 0,12 & 0,07 & 0,10 & 0,11 \\
\hline \multicolumn{2}{|c|}{$\begin{array}{c}\text { Rata-rata per } \\
\text { Tahun }\end{array}$} & 0,08 & 0,11 & 0,03 & 0,01 & 0,03 & 0,05 \\
\hline \multicolumn{7}{|c|}{ Return on Assets (ROA) Minimum } & 0,00 \\
\hline \multicolumn{7}{|c|}{ Return on Assets (ROA) Maksimum } & 0,21 \\
\hline
\end{tabular}

Sumber : Data Diolah

Dari tabel diatas, terlihat keadaan ratarata nilai perusahaan pada perusahaan Sub Sektor Keramik, Porselen dan Kaca yang terdaftar pada Bursa Efek Indonesia mengalami fluktuasi dan cenderung menurun.

\section{b. Analisis Deskrisptif Kuantitatif}

1) Regresi Linier Berganda

Analisis regresi linier berganda pada penelitian menggunakan SPSS versi 21 dapat terlihat pada Tabel 5:

Tabel 5

Hasil Analisis Regresi Linier Berganda Coefficients $^{\mathrm{a}}$

\begin{tabular}{|c|c|c|c|c|}
\hline \multirow[t]{2}{*}{ Mode } & & \multicolumn{2}{|c|}{$\begin{array}{l}\text { Unstandardized } \\
\text { Coefficients }\end{array}$} & \multirow{2}{*}{$\begin{array}{c}\text { Standardized } \\
\text { Coefficients } \\
\text { Beta }\end{array}$} \\
\hline & & B & $\begin{array}{l}\text { Std. } \\
\text { Error }\end{array}$ & \\
\hline \multirow{4}{*}{1} & $\begin{array}{l}\text { (Consta } \\
\text { nt) }\end{array}$ & 47,466 & 15,035 & \\
\hline & $\mathrm{CR}$ &,- 430 & 187 &,- 325 \\
\hline & SIZE & $-1,573$ & ,519 &,- 463 \\
\hline & ROA & 9,524 & 3,710 & 391, \\
\hline
\end{tabular}

a. Dependent Variable: PBV

Sumber: Hasil Pengolahan Data 
Berdasarkan Tabel 5, model persamaan regresi yang diperoleh adalah sebagai berikut:

$\hat{Y}=47,466-0,430 x_{1}-1,573 x_{2}+9,524 x_{3}$

Artinya, likuiditas, dan ukuran perusahaan berpengaruh negatif sedangkan profitabilitas berpengaruh positif terhadap nilai perusahaan pada Perusahaan Sub Sektor Keramik, Porselin, dan Kaca yang Terdaftar di Bursa Efek Indonesia.

\section{2) Koefisien Korelasi dan Determinasi} Tabel 6

Koefisien Korelasi dan Koefisien Determinasi

\begin{tabular}{|c|c|c|c|c|c|}
\hline \multicolumn{6}{|c|}{ Model Summary b } \\
\hline Model & $\mathrm{R}$ & $\begin{array}{c}\mathrm{R} \\
\text { Square }\end{array}$ & $\begin{array}{c}\text { Adjusted } \\
\text { R } \\
\text { Square }\end{array}$ & $\begin{array}{l}\text { Std. Error } \\
\text { of the } \\
\text { Estimate }\end{array}$ & $\begin{array}{l}\text { Durbin- } \\
\text { Watson }\end{array}$ \\
\hline 1 & ,766 & 587 & ,528 & 1,42621 & 2,090 \\
\hline
\end{tabular}

a. Predictors: (Constant), ROA, CR, SIZE

b. Dependent Variable: PBV

Sumber: Hasil Pengolahan Data

Dari Tabel 6, nilai $r$ adalah 0,766 yang berarti terdapat korelasi atau hubungan yang kuat antara variabel dependen (PBV) dengan variabel independennya (CR, Size dan ROA). Sementara koefisien determinasi (R Square) sebesar 0,587 , yang berarti $58,7 \%$ dari variabel nilai perusahaan dijelaskan oleh variabel likuiditas, ukuran perusahaan dan profitabilitas sisanya $41,3 \%$ dijelaskan oleh variabel lain yang tidak diteliti dalam penelitian ini.

\section{3) Uji Hipotesis}

a) Uji Simultan (Uji F)

Hasil uji F dapat dilihat pada Tabel 7.

$$
\begin{gathered}
\text { Tabel } 7 \\
\text { Hasil Uji F }
\end{gathered}
$$

ANOVA $^{\mathrm{a}}$

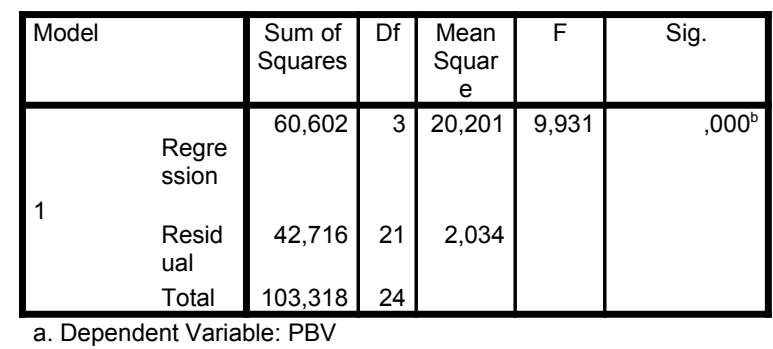

b. Predictors: (Constant), ROA, CR, SIZE

Sumber: Hasil Pengolahan Data (SPSS 21)

Dari Tabel 7 di atas, diperoleh nilai signifikansi $0,000<0,05$ maka $\mathrm{H}_{0}$ ditolak artinya likuiditas, ukuran perusahaan, dan profitabilitas berpengaruh signifikan terhadap nilai perusahaan pada Perusahaan Sub
Sektor Keramik, Porselin, dan Kaca yang terdafrtar di Bursa Efek Indonesia.

b) Uji Parsial (Uji t)

Hasil uji t dapat dilihat pada Tabel 8. Tabel 8

Hasil Uji t

\begin{tabular}{|c|c|c|c|c|c|c|}
\hline \multirow[t]{2}{*}{ Mod } & & \multicolumn{2}{|c|}{$\begin{array}{l}\text { Unstandardized } \\
\text { Coefficients }\end{array}$} & \multirow{2}{*}{$\begin{array}{c}\begin{array}{c}\text { Standa } \\
\text { rdized } \\
\text { Coeffic } \\
\text { ients }\end{array} \\
\text { Beta }\end{array}$} & \multirow[t]{2}{*}{$\mathrm{t}$} & \multirow[t]{2}{*}{ Sig. } \\
\hline & & $B$ & $\begin{array}{l}\text { Std. } \\
\text { Error }\end{array}$ & & & \\
\hline \multirow{4}{*}{1} & )$^{\text {(Constant }}$ & 47,466 & 15,035 & & 3,157 & ,005 \\
\hline & $\mathrm{CR}$ &,- 430 & 187 &,- 325 & $-2,304$ & ,032 \\
\hline & SIZE & $-1,573$ & ,519 &,- 463 & $-3,029$ & ,006 \\
\hline & ROA & 9,524 & 3,710 & ,391 & 2,567 & ,018 \\
\hline
\end{tabular}

Coefficients $^{\mathrm{a}}$

\section{Sumber: Hasil Pengolahan Data}

Dari Tabel 8 Likuiditas mempunyai nilai signifikansi 0,032 >0,05 maka $\mathrm{H}_{0}$ diterima artinya likuiditas berpengaruh negatif tidak signifikan terhadap nilai perusahaan.

Ukuran Perusahaan mempunyai nilai signifikansi $0,006<0,05$ maka $\mathrm{H}_{0}$ ditolak artinya ukuran perusahaan berpengaruh negatif signifikansi terhadap nilai perusahaan dan profitabilitas mempunyai nilai 0,018 $<0,05$ maka $\mathrm{H}_{0}$ ditolak artinya profitabilitas berpengaruh positif signifikansi terhadap nilai perusahaan pada Perusahaan Sub Sektor Keramik, Porselen dan Kaca yang terdaftar di Bursa Efek Indonesia.

\section{Evaluasi}

\section{a. Evaluasi Likuiditas pada}

Perusahaan Sub Sektor Keramik, Porselin dan Kaca yang terdaftar di Bursa Efek Indonesia

Hasil penelitian menunjukkan nilai ratarata Current Ratio (CR) Perusahaan Sub Sektor Keramik, Porselin dan Kaca berfluktuasi dan cenderung menurun. Nilai rata-rata $\mathrm{CR}$ sebesar 2,45, artinya setiap Rp 1 utang lancar di biayai oleh aset lancar sebesar Rp 2,45.

Nilai minimum CR sebesar 0,86 kali dan CR maksimum sebesar 5,68 kali. Pada saat CR perusahaan berada pada tingkat minimum, hal ini disebabkan peningkatan jumlah aset lancarnya perusahaan tidak sebanding dengan peningkatan utang lancar. Sedangkan pada saat CR berada pada tingkat maksimum disebabkan terjadi peningkatan pendanaan perusahaan dengan menggunakan aset lancar.

b. Evaluasi Ukuran Perusahaan pada Perusahaan Sub Sektor Keramik, Porselin dan Kaca yang terdaftar di Bursa Efek Indonesia

Hasil penelitian terlihat rata-rata Size Perusahaan Sub Sektor Keramik, Porselin dan Kaca yang terdaftar di Bursa Efek Indonesia 
mengalami fluktuasi dan cenderung mengalami peningkatan. Nilai rata-rata Size sebesar 28,70, artinya setiap Rp 1 perusahaan di biayai oleh jumlah aset sebesar $\mathrm{Rp} 28,70$. Nilai minimum Size sebesar 27,76 kali dan nilai maksimum adalah 29,68 kali. Pada saat Size perusahaan berada pada tingkat minimum, hal ini disebabkan jumlah aset perusahaan mengalami penurunan dari tahun sebelumnya. Sedangkan Size berada pada tingkat maksimum disebabkan terjadi peningkatan jumlah aset perusahaan.

c. Evaluasi Profitabilitas pada Perusahaan

Hasil penelitian terlihat rata-rata return on assets (ROA) Perusahaan Sub Sektor Keramik, Porselin dan Kaca yang terdaftar di Bursa Efek Indonesia mengalami fluktuasi dan cenderung menurun. Nilai rata-rata ROA sebesar 0,05 kali, artinya setiap Rp 1.00 total aset dapat menghasilkan laba bersih sebesar Rp 0,05. Nilai minimum ROA sebesar 0,00 kali dan nilai maksimum adalah 0,21 kali. Pada saat ROA perusahaan berada pada tingkat minimum, hal ini disebabkan laba bersih perusahaan mengalami penurunan dibandingkan dengan total aset. Sedangkan ROA pada tingkat maksimum disebabkan oleh peningkatan laba bersih pada tahun tersebut lebih tinggi daripada laba bersih dari tahun lainnya.

\section{d. Evaluasi Nilai Perusahaan pada} Perusahaan Sub Sektor Keramik, Porselen dan Kaca yang Terdaftar di Bursa Efek Indonesia

Hasil penelitian menunjukkan rata-rata Price to Book Value (PBV) Perusahaan Sub Sektor Keramik, Porselin dan Kaca berfluktuasi dan cenderung menurun. Rata-rata PBV adalah 1,79 kali. Nilai minimum PBV adalah sebesar 0,02 kali dan nilai maksimum adalah 7,95 kali. Pada saat PBV berada pada tingkat minimum, hal ini disebabkan oleh harga saham yang tinggi dari periode sebelumnya, sedangkan laba per lembar saham mengalami kenaikan rendah.

d. Evaluasi Pengaruh Likuiditas, Ukuran

Perusahaan dan Profitabilitas terhadap

Nilai Perusahaan pada Perusahaan Sub

Sektor Keramik, Porselin dan Kaca yang terdaftar di Bursa Efek Indonesia

Berdasarkan hasil regresi diketahui bahwa likuiditas memiliki pengaruh negatif terhadap nilai perusahaan, ukuran perusahaan memiliki pengaruh negatif terhadap nilai perusahaan dan profitabilitas memiliki pengaruh positif terhadap nilai perusahaan.

Besar pengaruh yang dimaksud untuk konstanta adalah 47,466 yang secara sistematis menyatakan bahwa jika nilai variabel bebas likuiditas, ukuran perusahaan dan profitabilitas bernilai nol maka nilai dari nilai perusahaan adalah sebesar 47,466. Likuiditas sebesar 0,430 berarti bahwa setiap variabel likuiditas meningkat sebesar satu satuan, nilai perusahaan akan menurun sebesar 0,430 kali satuan. Ukuran perusahaan sebesar 1,573 berarti bahwa setiap variabel ukuran perusahaan meningkat sebesar satu satuan, nilai perusahaan akan menurun sebesar 1,573 kali satuan dan sebaliknya profitabilitas sebesar 9,524 berarti bahwa setiap variabel profitabilitas meningkat sebesar satu satuan, nilai perusahaan akan menurun sebesar 9,524 kali satuan dan sebaliknya.

\section{KESIMPULAN DAN SARAN}

1. Kesimpulan

a. Berdasarkan hasil penelitian secara keseluruhan nilai rata-rata Current Ratio (CR) mengalami fluktuasi cenderung meningkat, namun terdapat 3 perusahaan nilai dibawah rata-rata yakni perusahaan ARNA MLIA dan TOTO pada Perusahaan.

b. Berdasarkan hasil penelitian secara keseluruhan nilai rata-rata size mengalami fluktuasi cenderung meningkat. Namun terdapat 3 perusahaan dengan nilai dibawah rata-rata yaitu perusahaan ARNA, KIAS dan TOTO pada Perusahaan Sub Sektor Keramik, Porselin, dan Kaca yang terdaftar di Bursa Efek Indonesia.

c. Berdasarkan hasil penelitian secara keseluruhan nilai rata-rata Return on Assets (ROA) mengalami fluktuasi namun cenderung menurun. Namun terdapat 2 perusahaan dengan nilai dibawah rata-rata yaitu perusahaan AMFG dan MLIA pada Perusahaan Sub Sektor Keramik, Porselin, dan Kaca yang terdaftar di Bursa Efek Indonesia.

d. Berdasarkan hasil penelitian secara keseluruhan nilai rata-rata nilai perusahaan yang dihitung dengan Price to Book Value (PBV) mengalami fluktuasi namun cenderung menurun. Namun ada terdapat 4 perusahaan yang nilai Price to Book Value (PBV) dibawah rata-rata yaitu perusahaan AMFG, KIAS, MLIA dan TOTO pada Perusahaan Sub Sektor Keramik, Porselin, dan Kaca yang terdaftar di Bursa Efek Indonesia.

e. Dari hasil pengujian regresi linier berganda diperoleh Likuiditas, dan ukuran perusahaan berpengaruh negatif sedangkan profitabilitas berpengaruh positif terhadap nilai perusahaan pada Perusahaan Sub Sektor Keramik, Porselin, dan Kaca yang Terdaftar di Bursa Efek Indonesia.

f. Dari uji koefisien korelasi dan determinasi diperoleh nilai korelasi atau hubungan yang sedang antara variabel bebas dengan variabel terikat. Sementara untuk hasil determinasi diketahui bahwa likuiditas 
(CR), ukuran perusahaaan (size), dan profitabilitas (ROA) berpengaruh $58,7 \%$ terhadap nilai perusahaan, sedangkan sisanya $41,3 \%$ dipengaruhi oleh faktor lainnya yang tidak dijelaskan dalam penelitian ini.

g. Dari hasil uji $F$ diperoleh bahwa secara simultan besarnya $F_{\text {hitung }}>F_{\text {tabel }} \mathrm{H}_{0}$ ditolak, artinya bahwa likuiditas, ukuran perusahaan, dan profitabilitas berpengaruh tidak signifikan terhadap nilai perusahaan pada Perusahaan Sub Sektor Keramik, Prselin, dan Kaca yang terdaftar di Bursa Efek Indonesia tahun 2013-2017.

h. Dari hasil uji t diperoleh bahwa secara parsial variabel likuiditas diketahui bahwa $t_{\text {hitung }}>t_{\text {tabel }}$ maka $\mathrm{H}_{0}$ ditolak artinya likuiditas berpengaruh negatif signifikan terhadap nilai perusahaan Sementara ukuran perusahaan $t_{\text {hitung }}>t_{\text {tabel }}$ maka $\mathrm{H}_{0}$ ditolak artinya ukuran perusahaan berpengaruh signifikansi terhadap nilai perusahaan pada Perusahaan Sub Sektor Keramik, Porselin, dan Kaca yang Terdaftar di Bursa Efek Indonesia

i. Sedangkan profitabilitas $t_{\text {nitung }}>t_{\text {tabel }}$ maka $\mathrm{H}_{0}$ ditolak artinya profitabilitas berpengaruh signifikansi terhadap nilai perusahaan pada Perusahaan Sub Sektor Keramik, Porselin, dan Kaca yang Terdaftar di Bursa Efek Indonesia.

2. Saran

a. Untuk meningkatkan profitabilitas perusahaan dapat melakukannya dengan cara memperbesar laba (margin laba) dan mengoptimalkan aset turnover (perputaran total aset).

b. Untuk meningkatkan nilai perusahaan sebaiknya perusahaan dapat meningkatkan laba dengan cara menambah utang yang memiliki laba bunga yang ringan untuk meningkatkan produktivitas dan penjualan. Penjualan meningkat diharapkan laba meningkat. Meningkatnya laba dapat meningkatkan profitabilitas.

\section{E. DAFTAR PUSTAKA}

Hery. 2015. Pengantar Akuntansi. Jakarta: Grasindo.

Brigham, Eugen F. Dan Joel F. Houston. 2001. Prinsip-Prinsip Manajemen Keuangan, Buku Satu, Edisi Kesebelas. Jilid 1. Jakarta: Salemba Empat.

Brigham, Eugen F. Dan Joel F. Houston.2012. Dasar-Dasar Manajemen Keuangan, Buku Satu, Edisi Kesebelas, Jakarta: Salemba Empat.

Kasmir. 2016. Pengantar Manajemen Keuangan, Edisi Ppertama. Cetakan Pertamaa.Jakarta:Kencana.

Kartikahadi, Hans, et, al., 2012, Akuntansi Keuangan Berdasarkan SAK Berbasis IFRS, Buku 1, Jakarta: Salemba Empat.

Keown, et. al., 2004, Manajemen Keuangan: Prinsip-Prinsip dasar dan Aplikasi, Edisi Kesimbalan, Jilid Satu, Jakarta: Indeks Kelompok Gramedia.

Kieso, E. Donald. Jerry J. Weygant, dan Terry D. Warfield. 2007. Akuntansi Intermediate. Edisi XII. Jilid 1. Jakarta: Erlangga. 